\title{
A CRITICAL REVIEW OF NATURAL GAS FLARES-INDUCED SECONDARY AIR POLLUTANTS
}

\section{J.A. SONIBARE}

Received: $25 / 11 / 08$

Accepted: 16/12/09

\author{
Environmental Engineering Research Laboratory \\ Department of Chemical Engineering \\ Obafemi Awolowo University \\ Ile-Ife, Nigeria
}

\begin{abstract}
Application of material balance analysis (in one of our previous studies) to natural gas flare in the upstream petroleum operations confirmed the emission of primary air pollutants in form of $\mathrm{CO}, \mathrm{CO}_{2}$, $\mathrm{NO}$, and $\mathrm{NO}_{2}$ from "sweet" natural gas while "sour" gas emits $\mathrm{SO}_{2}$ in addition; incomplete combustion may be an impetus for the release of volatile organic compounds (VOCs) into the atmosphere from this same source. In this article, the significance of these gaseous emissions in the formation of secondary air pollutants in the atmosphere is reviewed for the purpose of air pollution control strategy. The goal is to describe the formation mechanism, to determine the influencing factors in formation along with environmental impacts and to identify the required technological and policy control approach for an improved environmental protection.
\end{abstract}

KEYWORDS: primary air pollutants, secondary air pollutants, sulphate, nitrate, particulate, ozone.

\section{INTRODUCTION}

During upstream petroleum operations, flares are commonly used either for routine or emergency purpose in the removal of associated gas for safe operations. This may be considered a better alternative to vent boom due to the anticipated destruction of natural gas but the resulting several air pollutants identified as emission products from this activity calls for another approach in natural gas removal. Though IPCC (1996) recognized carbon dioxide $\left(\mathrm{CO}_{2}\right)$ and water $\left(\mathrm{H}_{2} \mathrm{O}\right)$ as major output from gas flares, Sonibare and Akeredolu (2004) predicted other products to include carbon monoxide $(\mathrm{CO})$, nitrogen oxide $(\mathrm{NO})$, and nitrogen dioxide $\left(\mathrm{NO}_{2}\right)$, from "sweet" natural gas while "sour" gas emits sulphur dioxide $\left(\mathrm{SO}_{2}\right)$ in addition. Incomplete combustion may be an impetus for the release of volatile organic compounds (VOCs) into the atmosphere from this same source. These additional products are attributed to the variations in operating conditions of gas flares and the gaseous emissions have degradation potential on the environment either as primary or secondary pollutants.

Sonibare and Akeredolu (2005) identified exposure period and pollutant concentrations as major factors influencing environmental impacts of these flares but the species considered in the study were those formed from the overall chemical reactions of the reaction equations. Kinetic mechanisms of combustion reactions are complex; for instance about 177 reactions steps were identified by Li and Williams (1999) as taking place in natural gas combustion. Though the claim by Strosher (2000) that most of these products are destroyed in the flame before release into the atmosphere could be justified, there is a need for the various products resulting from interaction between the emissions from these flares and atmospheric compositions to be accounted for, if only for environmental protection. In this study, efforts are made to identify some of these products that are of environmental concern.

During photochemical reactions in the atmosphere, free radicals formed including hydroxyl $\left(\mathrm{OH}^{*}\right)$, hydroperoxyl $\left(\mathrm{HO}_{2}{ }^{*}\right)$, methyl $\left(\mathrm{CH}_{3}{ }^{*}\right)$, single oxygen $\left(\mathrm{O}\left({ }^{1} \mathrm{D}\right)^{*}\right)$, and hydrogen $\left(\mathrm{H}^{*}\right)$ can react with any of the released gaseous emissions from natural gas flares to form new products which are referred to 
as secondary pollutants. In addition to radiation intensity which can influence these reactions are temperature and relative humidity (Folberth et al., 2003). The variation of the parameters with different periods of the year signifies the possibilities of concentrations variation of the various new products.

The impacts of air pollution on the environment make this study important for control purpose (Figure 1). Given the restricted availability of observations of some components in the atmosphere, there is always a need for calculated estimate of pollutants supply (EEA, 2003) and adequate knowledge of the species to account for as revealed in this study is considered a positive contribution to environmental protection. The study is expected to assist in protecting the hosts of natural gas flares in the petroleum producing areas of the world, especially the vulnerable sub-populations which may include people with chronic cardiac and respiratory conditions, the elderly, pregnant women, and newborns (Dickey, 2000). Concentration of these pollutants and resulting products of their reactions in the atmosphere is a function of original concentration from sources (Satsangi et al., 2002) and since consumption of some of the gaseous products can affect crop yields (Nelson et al., 2003) while the emitted compounds in the atmosphere can result in deposition (Lightawlers and Cape, 1998) which may encourage the transfer of the pollutants from air to water (Chevalier et al., 2003) or soil and vegetation (Bedell et al., 2003), this study is considered important to assist in providing adequate knowledge in mapping out monitoring strategy for better control implementation and scientifically motivated environmental management.

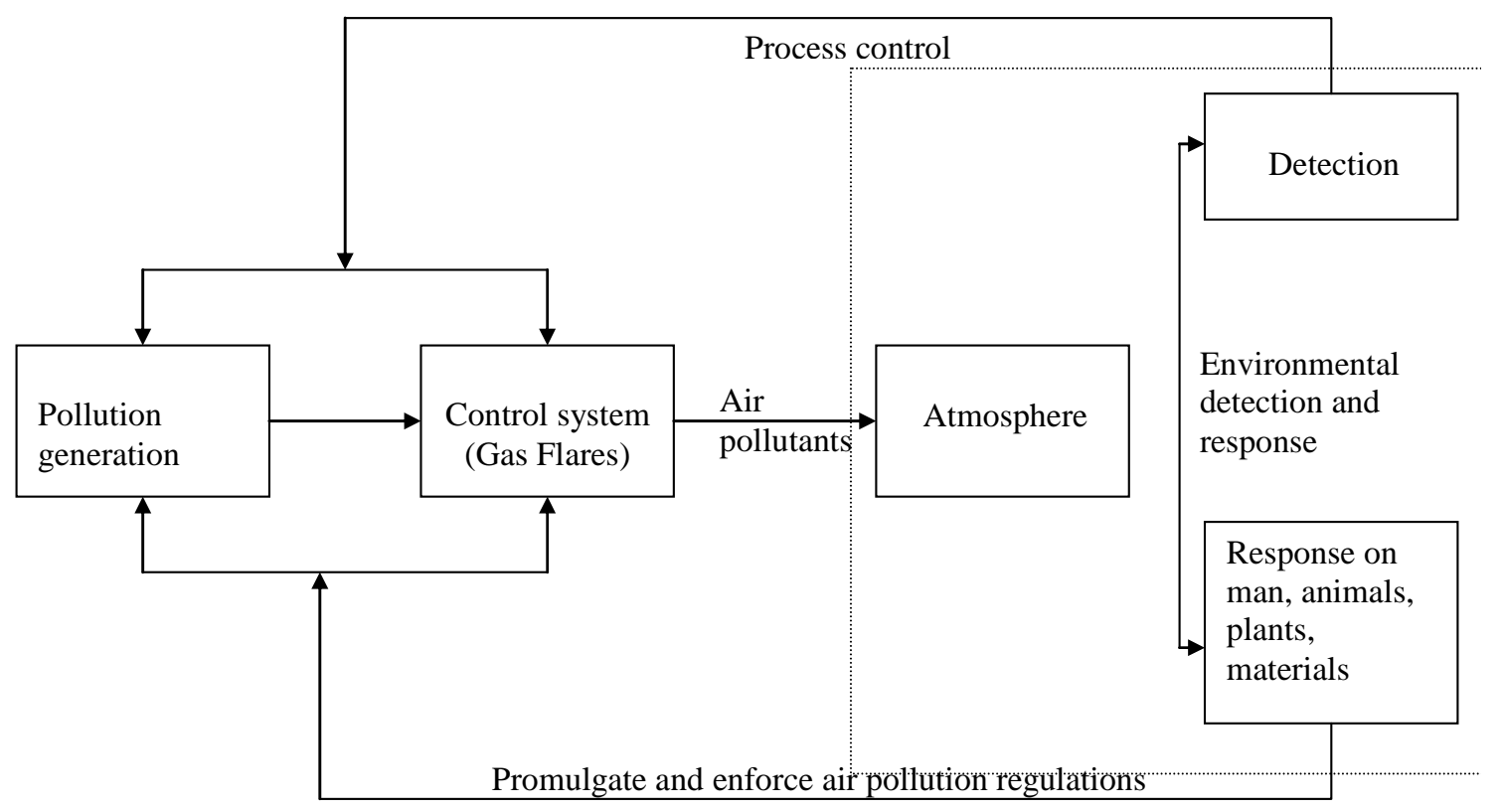

Figure 1. Elements of air pollution generation, prevention and control

(Adapted from Heinsohn and Kabel, 1999)

Soil moisture can be reduced by the presence of some of these gaseous emissions from flare in the soil (Savabi and Stockle, 2001) thus affecting crop yield and nutrients available for crops (Lieffering et al., 2004). There can also be a threat of toxic effect on both vegetation and soil (Beddel et al., 2003). Fevnades et al., (2002) demonstrated the possibility of $\mathrm{CO}_{2}$ and $\mathrm{CH}_{4}$ consumption by some crops while Ruth-Balaganskaya and Kudrijalt (2002) confirmed the possibility of sulphur products to become route for sulphur migration in the soil-plant system. Damage that can result from this gaseous emission consumption by vegetation can affect aesthetic value of plants and reduces their economic value as food (Westenbarger and Frisvold, 1994) and fiber. While serving as $\mathrm{SO}_{2}$ sink in the atmosphere (Johnson and Fegley, Jr, 2002), resulting water can become harmful to vegetation (Cape, 2003) just as the aquatic life can be affected (Havens et al., 1993). A reduction or total elimination of these gaseous emissions from the atmosphere has been identified as a way to reduce soil acidification (Pawlowski, 1997) but this can be done only if there is adequate knowledge on the factors influencing production as set out to be reviewed in this study. This and the global use of gas flares (Figure 2) are the reasons behind this review. 


\section{Secondary Air Pollutants}

Air pollutants which are substances in the air that could, if present in high enough concentrations, harm humans, animals, vegetation or material may be emitted directly from identifiable sources or produced in the air by interactions among two or more pollutants. While those emitted directly are classified as primary air pollutants, the later are generally termed

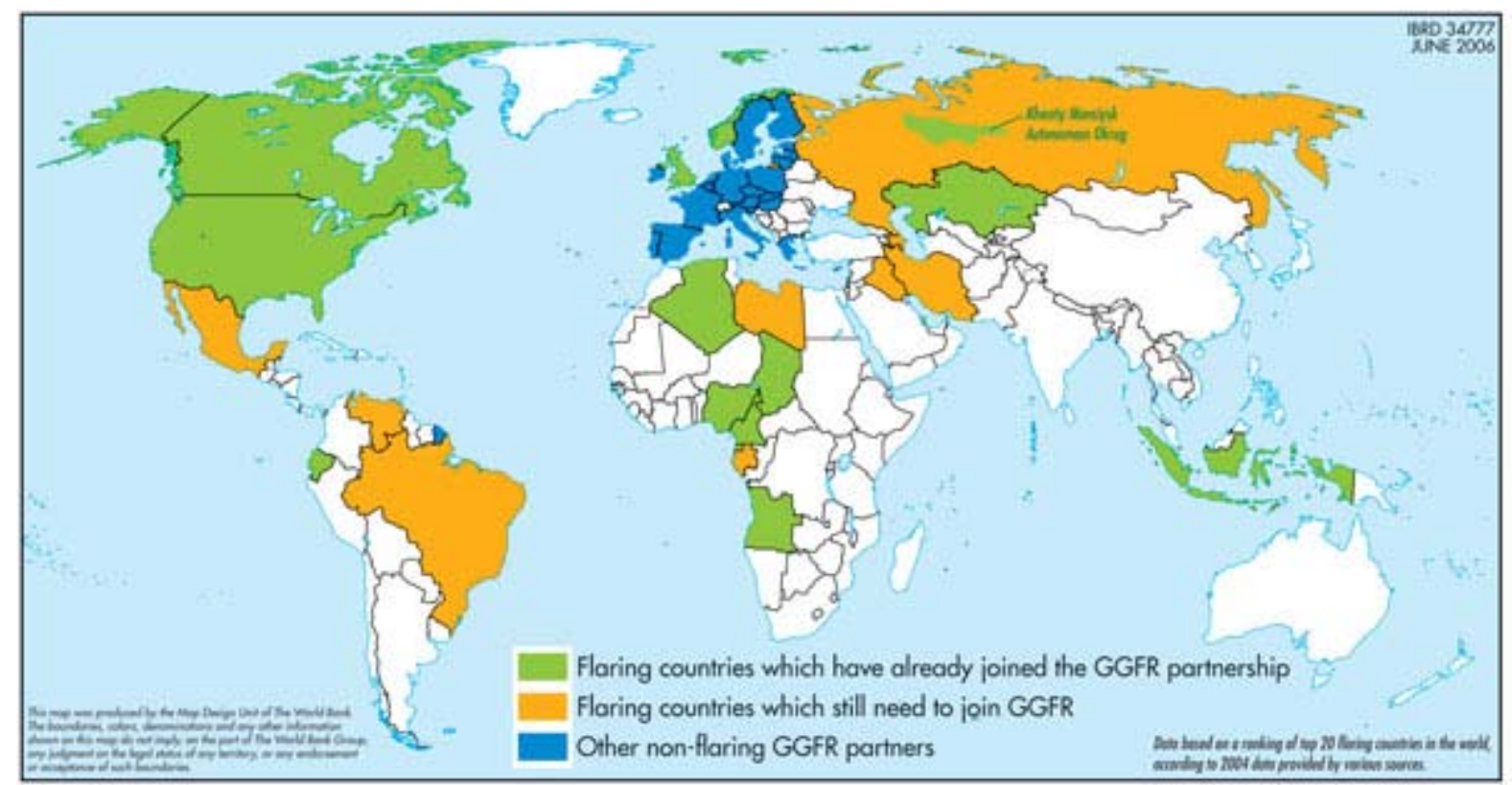

Figure 2. Global use of Gas Flares

secondary. Though the interaction among the primary air pollutants may require photo activation of the sun, this is not a necessary condition like the chemical reactions that must be involved (Jenkins and Clemitshaw, 2000). Secondary air pollutants are the oxidized products resulting from these interactions.

Impacts of the secondary air pollutants depend among other factors on the primary species interacting for their production and the resulting products. Adverse respiratory effects can occur due to their impacts on human (Bernstein, 2004) and some of the products may be toxic (Nazaroff and Weschler, 2004). Extensive literature survey revealed that secondary air pollutants from the products of interactions between earlier identified primary air pollutants in gas flares by Sonibare and Akeredolu (2004) and atmospheric compositions may include acid rain, particulates, and ozone and by inference, impacts of secondary pollutants from the equipment will include those from these three.

Acid rain, a secondary air pollutant which gained prominence in the late 1960s because of its perceived effects on ecosystem integrity (Menz and Seip, 2004) became a key environmental issue in 1980s (Yu et al., 1998). It is from nitrate and sulphate (Irwin et al., 2002) and usually results in the acidification of the environment (Table 1). Interests in controlling its precursors which include $\mathrm{SO}_{2}$ (Pirjola et al., 1999) and $\mathrm{NO}_{\mathrm{X}}$ stems from health concerns, particularly their effects in the form of particulate matter, another secondary air pollutant. The presence of sulphate may influence emission of methane in peat sites (Watson and Nedwell, 1998) thus creating further air pollution problems. Key findings show that acid rain continues to threaten sensitive aquatic and terrestrial ecosystems in some countries of the world (Fenech, 1998 and Peart, 2000) while groundwater can be acidified down to $\mathrm{pH} 4.4$ in the upper $3-4 \mathrm{~m}$ of saturated zone due to its impact (Kjoller et al., 2004). This indicates that agriculture in such an environment may be negatively affected. Furthermore, at certain temperature, there can be persistent negative effect on net photosynthesis of vegetation (Momen et al., 1999). Sulphuric acid, its major constituent, may impact negatively on historical buildings (Tecer, 1999 ) and it may decrease cement strength as well as affecting stone monuments made of marble and limestone (Xie et al., 2004). 
Table 1. Sulphuric and Nitric Acids as Major Sources of Acidity in Precipitation*

\begin{tabular}{l|c|c|c}
\hline Substance & $\begin{array}{c}\text { Concentration in } \\
\text { Precipitation } \\
\left(\mathrm{mg} \mathrm{L}^{-1}\right)\end{array}$ & $\begin{array}{c}\text { Contribution to Free } \\
\text { Acidity } \\
\text { (microequivalents L }\end{array}$ & $\begin{array}{c}\text { Contribution to Total } \\
\text { Acidity } \\
\text { (microequivalents L-1) }\end{array}$ \\
\hline $\mathrm{H}_{2} \mathrm{CO}_{3}$ & 0.62 & 0 & 20 \\
$\mathrm{NH}_{4}^{+}$ & 0.92 & 0 & 51 \\
$\mathrm{Al}$, dissolved & 0.05 & 0 & 5 \\
$\mathrm{Fe}$, dissolved & 0.04 & 0 & 2 \\
Mn, dissolved & 0.005 & 0 & 0.1 \\
Total organic acids & 0.34 & 2.4 & 4.7 \\
$\mathrm{HNO}_{3}$ & 4.40 & 39 & 39 \\
$\mathrm{H}_{2} \mathrm{SO}_{4}$ & 5.10 & 57 & 57 \\
\hline Total & & 98 & 179 \\
\hline
\end{tabular}

Source: Yen (1999)

When acid seeps into the soil, it may deplete soil minerals such as calcium, magnesium, potassium, and other trace nutrients essential to vegetation nutrition. Deposition of the highest acid concentration near the source as identified by Larseen et al., (1999) signifies the seriousness of the negative impact that the hosts of gas flares in the upstream petroleum operations of the world like the Niger Delta Area of Nigeria might be facing. Raputa et al., (2008) established the presence of both nitrate and sulphate at significant levels around oil-gas flare. Wind blown which is a function of the meteorology of the host area and alkaline soil dust influenced by soil structure and composition are important in neutralizing this acidity of the emissions. In addition, rain acidity attributed to $\mathrm{SO}_{4}{ }^{2-}$ can be neutralized by $\mathrm{NH}_{4}^{+}$and Ca with the neutralizing factors (NF) determined as (Kulshrestha et al., 1996):

$$
\begin{aligned}
& N F_{\left(\mathrm{NH}_{4}\right)}=\frac{\mathrm{NH}_{4}}{\mathrm{NO}_{3}+2 \mathrm{SO}_{4}} \\
& N F_{(\mathrm{Ca})}=\frac{\mathrm{Ca}}{2 \mathrm{NO}_{3}+\mathrm{SO}_{4}} \\
& N F_{(\mathrm{Mg})}=\frac{\mathrm{Mg}}{2 \mathrm{NO}_{3}+\mathrm{SO}_{4}}
\end{aligned}
$$

Ozone is formed by the gas-phase oxidation of hydrocarbons and carbon monoxide catalyzed by hydrogen oxide and nitrogen oxide radicals (Jacob, 2000) in the troposphere. In addition to the active participation of $\mathrm{NO}$ and $\mathrm{NO}_{2}$ in acid rain formation is the limiting factor characteristic they display in ozone production (Plummer et al., 1996) where VOCs and CO are oxidized. CO is one of the main reactive trace gases in the earth's atmosphere and it influences the atmospheric chemistry as well as the climate (Badr and Probert, 1995) thus playing important roles in the formation of secondary air pollutants like ozone. Ozone is a strong photochemical oxidant with its elevated concentrations in ambient air causing serious health problems and damage to ecosystems, agricultural crops and materials (EEA, 2002). Due to these, the European Council, in 1992, adopted a directive on air pollution by ozone (EEA, 2001) establishing procedures for harmonized monitoring of ozone concentrations, exchange of information, communication with and alerting of the population and to optimize the action required for its reduction. Ozone plays a significant role in $\mathrm{SO}_{2}$ oxidation in rainwater especially in the presence of $\mathrm{H}_{2} \mathrm{O}_{2}$ (Penkett et al., 2007).

Ozone toxicity occurs in a continuum and when in higher concentrations with longer exposure duration, the impacts may be severe (Table 2). A short- term exposure to its concentrations in the range of $120-240 \mu \mathrm{g} \mathrm{m}^{-3}$ and higher could lead to decrease in pulmonary function in children, adolescents, and young adults (WHO, 2000). There has been documented evidence that it might interfere with antimicrobial defenses thus promoting chest infections (DOH, 1998). Furthermore, exposure of ecosystems and agricultural crops to certain level of ozone can result in visible foliar injury and in reductions to crop yield and seed production (EEA, 2001a). Huixiang et al., (2005) suggested that the yields of winter wheat grown in the Yangtze Delta in 1999 and 2000 were likely reduced by about $20-30 \%$ as a result of damage caused by exposure to ambient ozone while Calatayud and Barreno (2001) reported efforts taken to combat ozone impacts in the reduction of the 
yield of several important agricultural crops in Spain. Assuming no change in agricultural production practices, (Wang and Mauzerall, 2004) projected grain loss due to increased levels of $\mathrm{O}_{3}$ pollution to increase to $2-16 \%$ for wheat, rice and corn and $28-35 \%$ for soybeans by the year 2020 . The associated economic costs are expected to increase by $82 \%, 33 \%$, and $67 \%$ in 2020 over 1990 for China, Japan and South Korea, respectively. To underpin practical recommendations aiming to increase the sustainability of agricultural land management in a changing environment and to secure food supply in regions with rapidly growing populations, Fuhrer and Booker (2003) stressed the need for research on the effects of ozone on agricultural crops and agro-ecosystems. To some vegetation species, the adverse effects can be noted at relatively low ozone levels. Other materials such as natural and synthetic rubbers, coatings and textiles can also be affected by ozone while its synergistic effects in combination with the acidifying components $\mathrm{SO}_{2}$ and $\mathrm{NO}_{2}$ have been reported to lead to increased corrosion on building materials like steel, zinc, copper, aluminium and bronze.

Table 2. Threshold Values for Ozone Concentrations*

\begin{tabular}{l|c|c}
\hline Threshold for: & $\begin{array}{c}\text { Concentration } \\
\left(\mathrm{\mu g} \mathrm{m}^{-3}\right)\end{array}$ & $\begin{array}{c}\text { Averaging Period } \\
(\mathrm{h})\end{array}$ \\
\hline Health protection & 110 & 8 \\
Vegetation protection & 200 & 1 \\
& 65 & 24 \\
Informing the population & 180 & 1 \\
Warning the population & 360 & 1 \\
\hline
\end{tabular}

*Source: (EEA, 2001a)

Particulate which is the third secondary air pollutant of importance comes in form of aerosol with $\mathrm{SO}_{4}{ }^{2-}$ and $\mathrm{NO}_{3}{ }^{-}$as some of the dominant species (Selma et al., 2001, Sun et al., 2004 and Chang and Lee, 2007) if the precursors i.e. primary pollutants are from natural gas flares. $\mathrm{NO}_{2}$ is precursor to $\mathrm{HNO}_{2}$ formation which may eventually result in $\mathrm{HNO}_{3}$ and nitrate aerosol formation (Park et al., 2005) while $\mathrm{SO}_{2}$ oxidation followed by binary $\mathrm{H}_{2} \mathrm{SO}_{4}-\mathrm{H}_{2} \mathrm{O}$ or ternary $\mathrm{H}_{2} \mathrm{SO}_{4}-\mathrm{H}_{2} \mathrm{O}-\mathrm{NH}_{3}$ nucleation usually results in the formation of aerosols (Alastair et al., 2004). In addition to both sulphate and nitrate aerosols are the secondary organic aerosol (SOAP) which depend strongly on the conversion of VOCs (Dechapanya et al., 2003) released from the gas flares. Though aerosol formation from primary air pollutants resulting from natural gas flares emissions usually takes place outdoor, the impacts on the environment may include indoor (Gauvin et al., 2002).

They are ubiquitous in the troposphere and of special interest since they contribute to both light scattering and absorption of radiation with consequential visibility and climate effects (Madhavi and Badarinath, 2004; Penner and Novakov, 1996). They also produce brighter clouds that are less efficient at releasing precipitation. These in turn may lead to large reductions in the amount of solar irradiance reaching Earth's surface, a corresponding increase in solar heating of the atmosphere, changes in the atmospheric temperature structure, suppression of rainfall, and less efficient removal of pollutants. The aerosol effects can lead to a weaker hydrological cycle, which connects directly to availability and quality of fresh water (Ramanathan et al., 2001). Chameides et al., (1999) suggested that resulting haze from atmospheric aerosols could depress optimal yields of $70 \%$ of the crops grown in China by at least $5-30 \%$. Other impacts may include health which are chronic mortality in adult (Pope et al., 1995) and infant (Bobak and Leon, 1999); asthma and other lower respiratory symptoms in adults (Dusseldorp et al., 1995) and children (Roemer et al., 1993); and chronic bronchitis in both adults (Abbey et al., 1995) and children (Dockery et al., 1993). Based on WHO (2002) global estimates, about 2.5 million deaths each year result from indoor exposures to particulate matter in rural and urban areas in developing countries, representing 4-5\% of the 50-60 million global deaths that occur annually. These effects may not be confined to the local area of production but extend at regional as well as global scales due to long transportation of aerosols (Mitra and Sharma, 2002).

\section{FORMATION MECHANISM}

Formation of the three identified natural gas flares-induced secondary pollutants can be described with the natural gas flare seen as a stationary source located in an unrestricted environment where it is directly emitting primary air pollutants into the atmosphere through plume (Figure 3). Primarily based on temperature, the atmosphere can be stratified as troposphere, stratosphere, and 
mesosphere (Figure 4), with the secondary air pollutants formed depending on the level of interaction between these primary air pollutants and the atmospheric composition which is about $79 \%$ nitrogen, $20 \%$ oxygen, and $1 \%$ other gases.

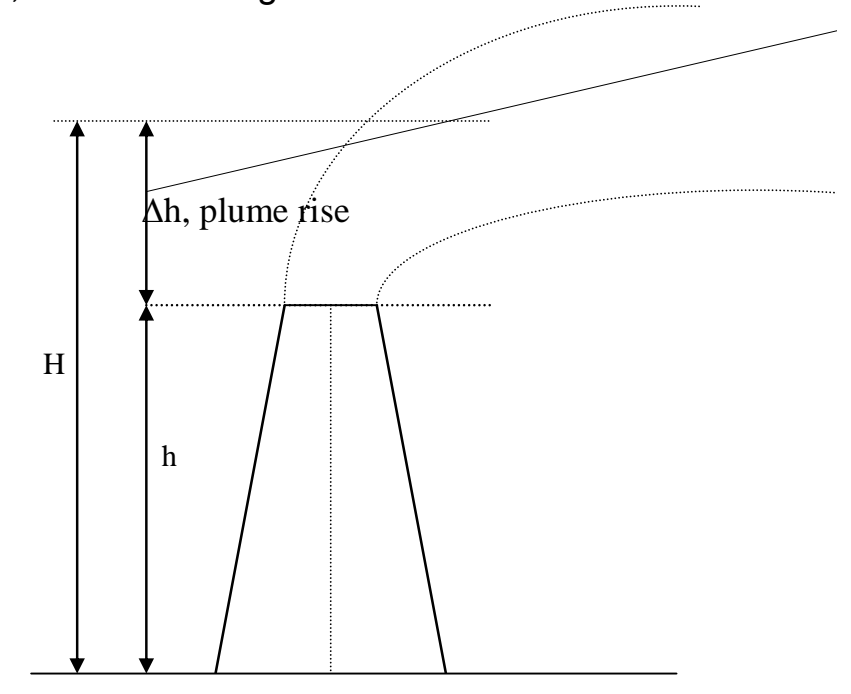

Figure 3. Natural Gas Flare with Plume rise

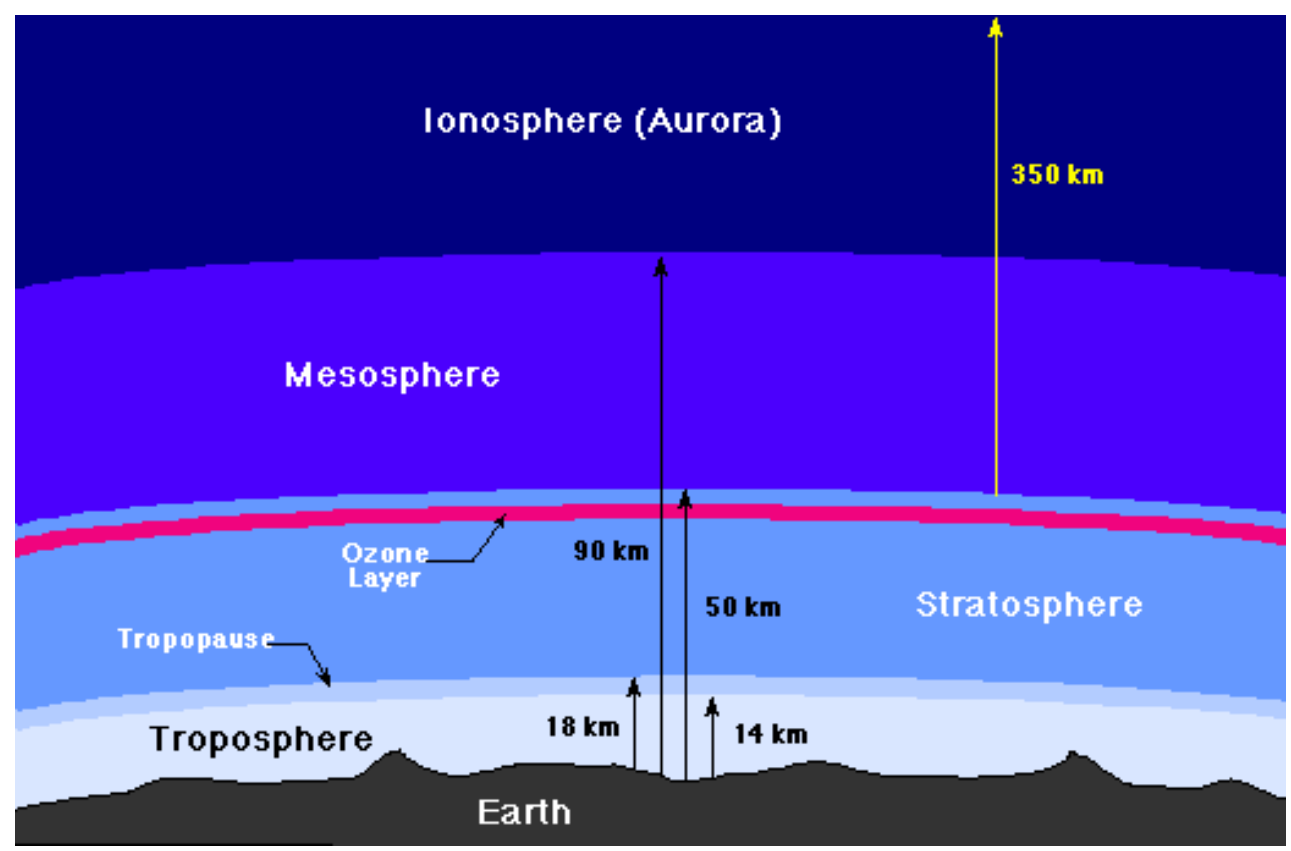

Figure 4. Atmospheric Stratification (http://csep10.phys.utk.edu/astr161)

The troposphere is the lowest layer of the atmosphere and the layer between the ground and up to about 15 and $10 \mathrm{~km}$ at the equator and poles respectively. There, the temperature decreases at the rate of $6.5^{\circ} \mathrm{C} \mathrm{km}^{-1}$ with a well mixed air and relatively strong thermally driven convection. It is where all weather takes place and at its top, the air pressure is about $10 \%$ of that at sea level. In the stratosphere, which is the layer between the troposphere and approximately $50 \mathrm{~km}$, there is an almost uniform temperature except in the upper part where it rises to approximately $0{ }^{\circ} \mathrm{C}$; this increase is attributed to the absorption of ultraviolet radiation by ozone from the ozone layer located therein. There is a little bulk mixing in this layer because the air flow is almost horizontal. The layer between 50 and $85 \mathrm{~km}$ is the mesosphere and in this region, the temperature variation is a linear decrease to approximately $175 \mathrm{~km}$. The uppermost layer of the atmosphere is the thermosphere and it is located above the mesosphere with the temperature increasing to about $1230^{\circ} \mathrm{C}$. Many atoms are ionized in the layer thus being labeled the ionosphere. This layer is very thin and is also responsible for absorbing the most energetic photons from the sun. Its structure is strongly 
influenced by the charged particle wind from the sun, which in turn, is governed by the level of solar activity.

Table 3. Composition of Atmospheric Air*

\begin{tabular}{|c|c|c|c|}
\hline Group & Species & $\begin{array}{l}\text { Average Concentration } \\
\text { (ppm) }\end{array}$ & $\begin{array}{c}\text { Approximate } \\
\text { Residence Time }\end{array}$ \\
\hline Major Species & $\begin{array}{l}\mathrm{N}_{2} \\
\mathrm{O}_{2} \\
\mathrm{H}_{2} \mathrm{O}\end{array}$ & $\begin{array}{l}780,840 \\
209,460 \\
\text { Variable }\end{array}$ & $\begin{array}{l}10^{6} \mathrm{yr} \\
10 \mathrm{yr}\end{array}$ \\
\hline Inert Gases & $\begin{array}{l}\mathrm{Ar} \\
\mathrm{Ne} \\
\mathrm{He} \\
\mathrm{Kr} \\
\mathrm{Xe}\end{array}$ & $\begin{array}{l}9,340 \\
18 \\
5.2 \\
1.1 \\
0.09\end{array}$ & \\
\hline Trace Species & $\begin{array}{l}\mathrm{CO}_{2} \\
\mathrm{CH}_{4} \\
\mathrm{H}_{2} \\
\mathrm{~N}_{2} \mathrm{O} \\
\mathrm{CO} \\
\mathrm{NH}_{3} \\
\mathrm{NO} / \mathrm{NO}_{2} \\
\text { Remote Regions } \\
\text { Rural continental United States } \\
\text { Urban } \\
\mathrm{O}_{3} \text { (troposphere) } \\
\mathrm{H}_{2} \mathrm{O}_{2} \\
\mathrm{HNO}_{3} \\
\mathrm{HCs} \\
\mathrm{HCHO} \\
\mathrm{HCOOH} \\
\mathrm{CH} \mathrm{H}_{3} \mathrm{OH} \\
\mathrm{CFC} 11\end{array}$ & $\begin{array}{l}350 \\
1.72 \\
0.58 \\
0.33 \\
0.05-0.2 \\
0.01 \\
\\
<0.00004 \\
0.00002-0.00005 \\
0.001 \\
0.02-0.05 \\
0.001 \\
0.001-0.0001 \\
0.001-0.050 \\
<0.0005-0.00075 \\
>0.02 \\
0.04-0.06 \\
0.003\end{array}$ & $\begin{array}{l}15 \mathrm{yr} \\
10 \mathrm{yr} \\
10 \mathrm{yr} \\
150 \mathrm{yr} \\
65 \text { days } \\
20 \text { days } \\
1 \text { day } \\
1 \text { day } \\
1 \text { day } \\
<1 \text { year } \\
1 \text { day }\end{array}$ \\
\hline $\begin{array}{l}\text { Sulphur } \\
\text { compounds }\end{array}$ & $\begin{array}{l}\mathrm{SO}_{2} \\
\mathrm{COS} \\
\mathrm{CS}_{2} \\
\mathrm{CH}_{3} \mathrm{SH} \\
\left(\mathrm{CH}_{3}\right)_{2} \mathrm{~S} \\
\mathrm{H}_{2} \mathrm{~S}\end{array}$ & $\begin{array}{l}0.0002 \\
0.0005 \\
0.00001-0.0002\end{array}$ & $\begin{array}{l}40 \text { days } \\
>0.03 \times 10^{5} \mathrm{~h} \\
>1.8 \times 10^{5} \mathrm{~h} \\
3-13 \mathrm{~h} \\
31 \mathrm{~h} \\
53 \mathrm{~h}\end{array}$ \\
\hline Free radicals & $\begin{array}{l}\mathrm{OH}^{*} \\
\mathrm{HO}_{2}{ }^{*}\end{array}$ & $\begin{array}{l}1-10 \times 10^{6} \text { molecules } \mathrm{cm}^{-3} \\
1 \times 10^{9} \text { molecules } \mathrm{cm}^{-3}\end{array}$ & \\
\hline
\end{tabular}

*Source: Heinsohn and Kabel (1999)

Depending on the altitude, temperature, and radiation wavelength, initiation reactions take place in the atmosphere in form of photolytic reactions from where other stages of the reactions set in. The other three general steps in formation mechanism are propagation reaction, branching reaction, and terminating reaction with production of radicals of various forms which include: hydroxyl $\left(\mathrm{OH}^{*}\right)$, hyrdroperoxyl $\left(\mathrm{HO}_{2}{ }^{*}\right)$, methyl $\left(\mathrm{CH}_{3}{ }^{*}\right)$, single oxygen $\left(\mathrm{O}\left({ }^{1} \mathrm{D}\right)^{*}\right)$, and hydrogen $\left(\mathrm{H}^{*}\right)$. Any of these radicals may react with emission products from natural gas flares for the formation of secondary products that may be of environmental concern. Considering the interaction between primary air pollutants released from natural gas flares (Sonibare and Akeredolu, 2004) and the various atmospheric compositions (Table 3 ) in each of the layers, a review of the reaction mechanism of the resulting secondary air pollutants is undertaken below:

\section{i. Acid Rain}

Through a series of complex chemical reactions, $\mathrm{SO}_{2}$ and $\mathrm{NO}_{x}$ emitted by natural gas flares are converted to acids that may result in rain acidity. Photochemical processes, because of their production of radicals, are strongly coupled to $\mathrm{SO}_{2}$ to form $\mathrm{H}_{2} \mathrm{SO}_{4}$ (Song et al., 2003): 


$$
\begin{aligned}
& \mathrm{SO}_{2}+\mathrm{OH} * \rightarrow \mathrm{HOSO}_{2} * \\
& \mathrm{HOSO}_{2} *+\mathrm{O}_{2} \rightarrow \mathrm{HO}_{2} *+\mathrm{SO}_{3} \\
& \mathrm{HO}_{2} *+\mathrm{NO} \rightarrow \mathrm{NO}_{2}+\mathrm{OH}{ }^{*} \\
& \mathrm{SO}_{3}+\mathrm{H}_{2} \mathrm{O} \rightarrow \mathrm{H}_{2} \mathrm{SO}_{4}
\end{aligned}
$$

According to Gundel et al., (1994), the reaction usually involves several atmospheric reactions which may include those heterogeneous reactions taking place within fog as:

$$
\begin{aligned}
& 2 \mathrm{SO}_{2}+\mathrm{O}_{2}+\text { Catalyst } \rightarrow 2 \mathrm{SO}_{3} \\
& \mathrm{SO}_{3}+\mathrm{H}_{2} \mathrm{O} \rightarrow \mathrm{H}_{2} \mathrm{SO}_{4}
\end{aligned}
$$

The catalyst in equation (5) above may be ammonia and when this is the case, rapid acidic component of the atmosphere may be produced in the conversion process (Renard et al., (2004).

Likewise, nitric acid formation in the atmosphere is generally by reactions of NO from the gas flares with both the hydroxyl and hydroperoxyl radicals while the conversion of $\mathrm{NO}_{2}$ is usually achieved via a one step mechanism into inorganic nitrate (Bottenheim et al., 1984):

$$
\begin{aligned}
& \mathrm{NO}+\mathrm{HO}_{2}^{*} \rightarrow \mathrm{NO}_{2}+\mathrm{OH}^{*} \\
& \mathrm{NO}_{2}+\mathrm{OH}^{*}+\mathrm{M} \rightarrow \mathrm{HNO}_{3}+\mathrm{M}
\end{aligned}
$$

This formation of nitric acid is a function of the time of the day:

(During daytime)

$$
\begin{aligned}
& \mathrm{NO}+\mathrm{HO}_{2} *+\mathrm{M} \rightarrow \mathrm{NO}_{2}+\mathrm{OH} \\
& \mathrm{NO}_{2}+\mathrm{OH}^{*}+\mathrm{M} \rightarrow \mathrm{HNO}_{3}+\mathrm{M}
\end{aligned}
$$

$$
\begin{aligned}
& \text { (At night) } \\
& \mathrm{NO}_{2}+\mathrm{O}_{3} \rightarrow \mathrm{NO}_{3}+\mathrm{O}_{2} \\
& \mathrm{NO}_{2}+\mathrm{O}_{3} \rightarrow \mathrm{N}_{2} \mathrm{O}_{5} \\
& \mathrm{~N}_{2} \mathrm{O}_{5}+\mathrm{H}_{2} \mathrm{O} \rightarrow 2 \mathrm{HNO}_{3}
\end{aligned}
$$

Though formation and deposition of nitric acid on surfaces is a popular irreversible sink of nitrogen oxides $\left(\mathrm{NO}_{\mathrm{X}}\right)$, the reaction of nitric oxide with nitric acid may convert $\mathrm{HNO}_{3}$ to photochemically active $\mathrm{NO}_{x}$ (Knipping and Dabdub, 2002) in the atmosphere. If nitrous acid is formed during the conversion stage, this is usually oxidized to nitric acid by $\mathrm{O}_{2}, \mathrm{O}_{3}$, and $\mathrm{H}_{2} \mathrm{O}_{2}$ in aqueous solution (Damschen and Martin, 1983; Calderon et al., 2008). To fully understand the status and mechanism of acid rain, it is important to know the $\mathrm{pH}$ of precipitation and its chemical constituents (Okuda et al., 2005) in the area of interest over a period of time.

\section{ii. Ozone}

In the atmosphere, three major sources of ozone may include the stratosphere, the free troposphere, and the boundary layer photochemical reactions (Derwent and Kay, 1988) with the direct formation generally being the reaction:

$$
\mathrm{O}+\mathrm{O}_{2}+\mathrm{M} \rightarrow \mathrm{O}_{3}+\mathrm{M}
$$

where $\mathrm{M}$ is a molecule such as $\mathrm{N}_{2}$ or $\mathrm{O}_{2}$ whose participation is necessary to conserve energy and momentum. Several reactions and processes are required via initiation, propagation, branching before the termination stage represented in equation (9). The troposphere alone where ozone is produced as a secondary air pollutants harbors about 59 reactions and 23 species for this purpose (Heard et al., 1998). The necessary ingredients for the formation are sunlight, volatile organic compounds, and nitrogen oxides $\left(\mathrm{NO} / \mathrm{NO}_{2}\right)$. Summarily, it is formed by photolytic reactions of $\mathrm{NO}_{2}$ via the reaction of oxygen radical with $\mathrm{O}_{2}$. During this process, the $\mathrm{O}\left({ }^{1} \mathrm{D}\right)^{*}$ radical reacts with water vapour to produce hydroxyl radicals $\left(\mathrm{OH}^{*}\right)$ or with methane to form methyl and hydroxyl radicals which play active role in the formation of other pollutants: 


$$
\begin{aligned}
& \mathrm{NO}_{2}+\mathrm{hv} \rightarrow \underset{\mathrm{NO}+\mathrm{O}\left({ }^{1} \mathrm{P}\right)}{\mathrm{NO}+\mathrm{O}\left({ }^{1} \mathrm{D}\right)^{*}} \quad \lambda<244 \mathrm{~nm} \\
& \begin{array}{l}
\mathrm{O}\left({ }^{1} \mathrm{D}\right) *+\mathrm{H}_{2} \mathrm{O} \rightarrow \mathrm{OH}^{*}+\mathrm{OH} \\
\mathrm{O}\left({ }^{3} \mathrm{P}\right) *+\mathrm{O}_{2}+\mathrm{M} \rightarrow \mathrm{O}_{3}+\mathrm{M}
\end{array}
\end{aligned}
$$

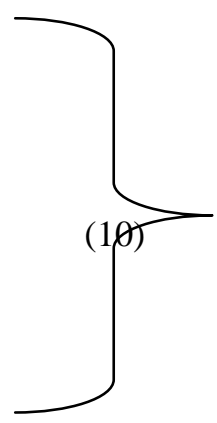

As sunlight becomes more intense later in the day, nitrogen dioxide is broken down thus increasing the concentration of ozone. Like the peroxyl radicals, the main role of VOCs (volatile organic compounds) is to prevent the ozone formed from being immediately consumed by NO to produce $\mathrm{NO}_{2}$ in the following reaction (Curtiss and Rabl, 1996):

$$
\mathrm{NO}+\mathrm{O}_{3} \rightarrow \mathrm{O}_{2}+\mathrm{NO}_{2}
$$

However, as sun disappears, the production of ozone is halted (Kumar and Mohan, 2005) while the remaining ozone in the atmosphere may then be consumed by several different reactions thus resulting in downward concentration. Ozone episodes with concentrations above $50 \mathrm{ppb}$ are quite frequent and its formation is to a large extent limited by the emissions of NMVOCs (NEGTAP, 2001).

\section{iii. Aerosols}

The presence of aerosols in the atmosphere is very important because of the various associated impacts and this has necessitated continuous studies of their formation mechanism for effective control strategy. Primary air pollutants of interest from natural gas flares for the formation of aerosols include $\mathrm{NO} / \mathrm{NO}_{2}, \mathrm{SO}_{2}$, and volatile organic compounds with nitrate, sulphate, and secondary organic aerosols respectively as resulting aerosols and the conversion is usually due to gas-to-particle conversions (Funasaka et al., 1999). An essential prerequisite for any of these gases to particle conversions is the presence of the species in the gas phase at a partial pressure in excess of its saturation vapour concentration with respect to the condensed phase (i.e. condensable material). In the experimental and model studies by Sarwar et al., (2003), it was demonstrated that secondary particle mass concentrations increase substantially with lower air exchange rates.

Generally, important aerosol formation processes include nucleation, condensation, and coagulation but Kermiren and Wexler (1995) indicated that for real growth to be experienced, aqueous-phase reactions in droplets or aerosol particles and reactions taking place at the interphase of two phases are additional stages. However, Clement and Ford (1999) identified an initial growth phase before the coagulation. Nucleation, the important first step in atmospheric aerosol formation may be affected by some factors like ion-induced and homogeneous nucleation, depletion of nanoparticles and ions on the pre-existing aerosol, nano-kohler growth function, the molecule-particle interception geometry, quantum retardation of sticking, electric charges of particles, molecular dipole moments, and the polarization interaction. Whatever the formation mechanism, meteorological parameters have been identified as some of the very strong factors influencing aerosol formation (Hrdličková et al., 2008). For the purpose of the set goals of this review work, the important reaction mechanism for nitrate, sulphates, and secondary organic aerosols are discussed below:

\section{a. $\quad$ Nitrate}

This is a very key secondary particulate generally formed as a result of atmospheric reactions of $\mathrm{NO} / \mathrm{NO}_{2}$ involving gas to particle conversion (Michalski et al., 2004). In the lower troposphere, oxidized $\mathrm{NO}$ (Eqn. 7) and the emitted $\mathrm{NO}_{2}$ from natural gas flares react with ozone to produce nitrate compound (Eqn. 8). The $\mathrm{HNO}_{3}$ produced from this reaction between $\mathrm{N}_{2} \mathrm{O}_{5}$ and $\mathrm{H}_{2} \mathrm{O}$ predominantly occurs in the cloud water and on the surface of particulate, involving the "charge transfer" or "ionic" intermediate $\mathrm{NO}_{2}{ }^{+} \mathrm{NO}_{3}{ }^{-}$, with the product being nitrate aerosol and not gaseous $\mathrm{HNO}_{3}$. However, in the presence of ammonia, ammonium nitrate is formed as secondary aerosol by gaseous $\mathrm{HNO}_{3}$ (Eqn. 12). In addition to ambient temperature, ammonia concentration influences the aerosol formation (Russel et al., 1983). When required precursors for the formation of ammonium nitrate are absent, heterogeneous reactions on the existing particles take predominant in the fine mode formation (Matsumoto and Tanaka, 1996). 


$$
\mathrm{HNO}_{3}(g)+\mathrm{NH}_{3}(g) \Leftrightarrow \mathrm{NH}_{4} \mathrm{NO}_{3}(\mathrm{~s}, \mathrm{aq} .)
$$

\section{b. Sulphate}

Apart from the nitrates, another important form of secondary aerosol is the sulphate which is principally formed from atmospheric conversion of $\mathrm{SO}_{2}$ produced by the natural gas flares. Its formation is usually either in the gas (Eqn. 13) or aqueous phases (Eqn. 14) with hydroxyl and hydroperoxyl radicals as important reacting agent (Stein and Lamb, 2003):

The gas phase :

$$
\mathrm{SO}_{2}+\mathrm{OH} \stackrel{\mathrm{O}_{2}, \mathrm{H}_{2} \mathrm{O}}{\rightarrow} \mathrm{SO}_{4}^{2-}+\mathrm{HO}_{2}
$$

The aqueous phase :

$$
\mathrm{SO}_{2}+\mathrm{H}_{2} \mathrm{O}_{2} \stackrel{\text { cloud }}{\rightarrow} \mathrm{SO}_{4}^{2-}
$$

Formation of new nuclei in sulphate aerosols is expected to be mainly the result of binary homogeneous nucleation of sulphuric acid/water droplets. This nucleation rate is a function of vapour phase acid mass concentration, the atmospheric relative humidity, and temperature. When there is a decrease in temperature but increase in both concentration and relative humidity, there can be significant increase in nucleation rate (Clement and Ford, 1999). Condensation on existing aerosol is a mechanism that may compete with nucleation. Though aqueous phase oxidation is the predominant mechanism for sulphate formation under fog conditions followed by condensation of the $\mathrm{H}_{2} \mathrm{SO}_{4}$ system, nucleation burst ascribed to high local sulphuric acid concentration by Lazaridis and Skouloudis (1999) may cease new particle formation.

\section{c. Secondary Organic Aerosols (SOAP)}

Certain classes of VOCs are more likely to lead to aerosol formation by their general high reactivity and types of oxidation products. Some of these VOCs are emitted by flare while the resulting aerosols are SOAP. Winiwarter and Puxbaum (2003) summarized the SOAP formation pathway as shown in Figure 5 . When the strong oxidants $\left(\mathrm{O}_{3}\right.$, hydroxyl, and nitrate radicals inclusive) react with the VOCs in the atmosphere, the stable molecule is broken down to form new radicals. These new radicals rapidly undergo a chain of reactions to form new compounds some of which have considerably lower volatility than the original VOCs. At sufficiently high partial pressure, the resulting condensable organic carbon can be converted into particulate phase while further agglomeration reactions possibly increase the molecule size at the same time decreasing volatility and ultimately fixing the molecule to particulate phase. These compounds are always fine in nature and may result in elevated $\mathrm{PM}_{2.5}$ concentrations of an area as observed by Brook et al., (2004).

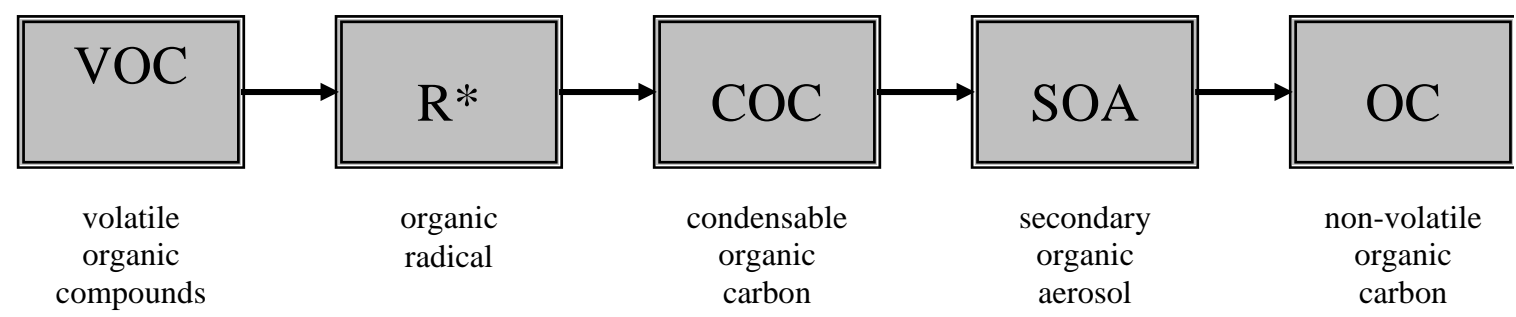

Figure 5. Secondary Organic Aerosol (SOA) Formation Pathway

Control Implications of Flare-Induced Secondary Air Pollutants Formation in the Atmosphere Without the possible impacts of the secondary air pollutants capable of being formed in the atmosphere by primary air pollutants from natural gas flares as highlighted in this review, Akeredolu and Sonibare (2004) reported that the environmental degradation potential of flares in terms of gaseous concentration is directly proportional to the gaseous concentration emitted. The requirement of these gaseous concentrations as active ingredients in secondary air pollution formation as shown in the formation mechanism review is an indicator that a total control on the emissions from flares may be a significant way of limiting flare-induced secondary air pollutants to 
the least possible level. Various difficulties including trans boundary air pollution and life time of primary pollutants that may be encountered in the control of atmospheric compositions strongly support this. Though NO has a very short life time thus may not encourage regular formation of secondary pollutants, the long life time of $\mathrm{SO}_{2}, \mathrm{CO}$, and $\mathrm{CO}_{2}$ which is about 3 days, 30 days, and 4 years respectively (Glazunor et al., 2001) indicates an otherwise situation.

The control of gaseous emissions from natural gas flares can be addressed in two ways: technology and policy. In using technology approach, the focus will be on the gas flare equipment releasing the primary air pollutants. For instance, IPCC (1994) and IPCC (1996) indicated that the state of combustion equipment plays prominent role in the nature of their emission products, an indication that a good maintenance culture may reduce the concentration of primary air pollutants coming from natural gas flares during the combustion activities. Likewise, the conclusion of Sonibare and Akeredolu (2004) that the operating conditions of natural gas flares are strong enough to determine the type of primary air pollutants released as emission products makes it mandatory for the operators of these gas flares in the oil fields to be conscious of suitable operating conditions that will reduce the number of gaseous species released at a point in time. Effective control of operating gas flare operating temperatures may be an indirect way of controlling $\mathrm{NO}_{x}$ emissions which may be a way of reducing the formation of both acid rain in form of $\mathrm{HNO}_{3}$ and aerosols in form of nitrate. In the process of piping natural gas into the flare boom, the knockout drum is a necessary route that must be taken for liquid removals (Akeredolu and Sonibare, 2004) to encourage efficient combustion and preserve the life of flare boom. If this removal approach can be applied to sour gas for sulphur compounds removal then, it may be possible to prevent $\mathrm{SO}_{2}$ formation thus eliminating it from the species of primary air pollutants. The use of fuzzy logic to constantly monitor the efficiency of the removal approach as demonstrated by Lia et al., (2008) can assist greatly in achieving the desired level. Like in the $\mathrm{NO}_{x}$ control, absence of $\mathrm{SO}_{2}$ from the primary air pollutants is a way to control acid rain and aerosols formation but in form of both $\mathrm{H}_{2} \mathrm{SO}_{4}$ and sulphate respectively. Furthermore, the removal technology can be extended to flue gas in form of gas scrubbers for the removal of both $\mathrm{NO}_{\mathrm{X}}$ and $\mathrm{SO}_{2}$ but this may be cost intensive if at all technologically feasible.

Policy option in controlling the formation of flare-induced natural gas flares may require the inputs of every stakeholder. Though atmospheric compositions may be difficult to control as mentioned earlier, the use of appropriate policy formulation may assist to some level. Active radicals are required in the atmosphere to react with these primary air pollutants in the formation of secondary pollutants thus any policy that may result in the reduction of these radicals formation is an indirect way of control. For instance, hydroxyl radicals are very important in the formation of these pollutants thus whatever will discourage their formation in the atmosphere can reduce their impacts in the formation activity. $\mathrm{NH}_{4} \mathrm{NO}_{3}$ and ammonium sulphate $\left(\mathrm{NH}_{4} \mathrm{SO}_{4}\right)$ are very common secondary aerosols but their formation can be controlled if the key agents are not encouraged to react. Even if $\mathrm{NO}_{x}$ and $\mathrm{SO}_{2}$ are released into the environment, the absence of $\mathrm{NH}_{3}$ is a way of putting these aerosols formation to a check. Cattle dung which is a common source of $\mathrm{NH}_{3}$ may be avoided and a policy discouraging cattle rearing around natural gas flare installations may be an effective way of using policy formulation to control these secondary aerosols formation. Since the secondary air pollutant formation mechanism depends strongly on the primary air pollutant presence and concentration, a policy that encourages profitable use of associated natural gas thus eliminating natural gas flares may be a most effective way of control. For example, upstream petroleum producers may be made to pay market price of natural gas or LPG (which ever is most costly) for every cubic metre of gas flared while incentives should be given to profitable utilizing operators.

\section{Conclusion}

Three important secondary air pollutants formed in the atmosphere due to the presence of primary air pollutants from natural gas flares have been reviewed with their environmental impacts and formation mechanisms discussed for the purpose of control measures. It has been shown that these secondary air pollutants can affect man, vegetation, and other materials thus leaving both health and economic impacts to tackle. Various factors required in the formation of these secondary air pollutants showed that the control of emissions of the primary air pollutants may be the easiest way to minimize the formation of the secondary air pollutants; both technology and policy options were considered. 


\section{REFERENCES}

Abbey D.E., Lebowitz M.D., Mills P.K., Petersen F.F., Lawrence Beeson W. and Burchette R.J. (1995), Longterm ambient concentrations of particulates and oxidants and development of Chronic Disease in a Cohort of Nonsmoking California Residents, Inhalation Toxicology, 7, 19-34.

Akeredolu F.A. and Sonibare J.A. (2004), A Review of the Usefulness of Gas Flares in Air Pollution Control, Management of Environmental Quality: An International Journal, 15(6), 574 - 583.

Alastueya A., Querola X., Rodrıgueza S., Planaa F., Lopez-Solera A., Ruizb C., and Mantillac E. (2004), Monitoring of Atmospheric Particulate Matter around Sources of Secondary Inorganic Aerosol, Atmospheric Environment, 38, 4979-4992.

Badr O. and Probert S.D. (1995), Sinks and Environmental Impacts for Atmospheric Carbon Monoxide, Applied Energy, 50, $339-372$.

Bedell J., Briant A., Delolme C. and Perrodin Y. (2003), Evaluation of the Phototoxicity of Contaminated Sediments Deposited "on soil". I. Impact of Water Draining from the Deposit on the Germination of Neighbouring Plants, Chemosphere, 50 (3), 393 - 402.

Bernstein J.A. (ed) (2004), Health Effects of Air Pollution, Journal of Allergy and Clinical Immunology, 114 (5), 1116-1123.

Bobak M. and Leon D.A. (1999), The effect of air pollution on infant mortality appears specific for respiratory causes in the postneonatal period, Epidemiology, 10(6), 666-670.

Bottenheim J.W., Brice K.A., and Anlauf K.G. (1984), Discussion of a Lagrangian Trajectory Model Describing Long-Range Transport of Oxides of Nitrogen, the Incorporation of PAN in the Chemical Mechanism, and Supporting Measurements of PAN and Nitrate Species at Rural Sites in Ontario, Canada, Atmospheric Environment (1967), 18(12), 2609-2619.

Brook J.R., Strawbridge K.B., Snyder B.J., Boudries H., Worsnop D., Sharma S., Anlauf K., Lu G. and Hayden K. (2004), Towards an Understanding of the Fine Particle Variations in the LFV: Integration of Chemical, Physical, and Meteorological Observations, Atmospheric Environment, 38(34), 5775 - 5788.

Bruce N., Perez-Padilla R. and Albalak R. (2002), The Health Effects of Indoor Air Pollution Exposure in Developing Countries. WHO/SDE/OEH/02.05, World Health Organization, Geneva.

Calatayud A. and Barreno E. (2001), Chlorophyll a Fluorescence, Antioxidant Enzymes and Lipid Peroxidation in Tomato in Response to Ozone and Benomyl, Environmental Pollution, 115(2), 283289

Calderón S.M., Poor N.D., Campbell S.W., Tate P. and Hartsell B (2008), Rainfall Scavenging Coefficients for Atmospheric Nitric Acid and Nitrate in a Subtropical Coastal Environment, Atmospheric Environment, 42(33), 7757-7767.

Cape J.N. (2003), Effects of Airborne Volatile Organic Compounds on Plants, Environmental Pollution, 122(1), $145-157$.

Chameides W.L., Yu H., Liu S.C., Bergin M., Zhou X., Mearns L., Wang G., Kiang C.S., Saylor R.D., Luo C., Huang Y., Steiner, A., Giorgi F., (1999), Case Study of the Effects of Atmospheric Aerosols and Regional Haze on Agriculture: An Opportunity to Enhance Crop Yields in China Through Emission Controls?, PNAS, 96(24), 13626 - 13633.

Chang S. and Lee C. (2007), Secondary Aerosol Formation through Photochemical Reactions Estimated by using Air Quality Monitoring Data in Taipei City from 1994 to 2003, Atmospheric Environment, 41(19), 4002-4017.

Chevalier J., Rouseaus P., Benoit V. and Benadda B. (2003), Environmental Assessment of Flue Gas Cleaning Processes of Municipal Solid Waste Incinerators by Means of the Life Cycle Assessment Approach, Chemical Engineering Science, 58(10), 2053 - 2064.

Clement C.F. and Ford I.J. (1999), Gas-to-Particle Conversion in the Atmosphere: I Evidence from Empirical Atmospheric Aerosols, Atmospheric Environment, 33, 475 - 487.

Curtiss P.S. and Rabl A. (1996), Impact Analysis for Air and Water Pollution: Methodology and Software Implementation. In: Zannetti, P. (ed.) Environmental Modeling, 3, Chapter 13, 393-426, Computational Mechanics Publications, Southampton.

Damschen D.E. and Martin L.R. (1983), Aqueous aerosol oxidation of nitrous acid by $\mathrm{O}_{2}, \mathrm{O}_{3}$ and $\mathrm{H}_{2} \mathrm{O}_{2}$, Atmospheric Environment (1967), 17(10), 2005-2011.

Dechapanya W., Eusebi A., Kimura Y. and Allen D.T. (2003), Secondary Organic Aerosol Formation From Aromatic Precursors. 1. Mechanisms for Individual Hydrocarbons, Environ Sci Technol., 37(16), 36623670.

Dickey J.H. (2000), Selected Topics Related to Occupational Exposures Part VII. Air Pollution: Overview of Sources and Health Effects, Disease-a-month, 46(9), 566 - 589.

Dockery D.W., Pope III C.A., Xiping Xu, Spengler J.D., Ware J.H., Fay M.E., Ferris B.G. and Speizer F.E. 
(1993), An association between air pollution and mortality in six US cities, New England J of Medicine, 329, 1753-1759.

DOH (1998), Quantification of the Effects of Air Pollution on Health in the United Kingdom. Committee on the Medical Effects of Air Pollutants, Department of Health, London, United Kingdom. pp. 78.

Dusseldorp A., Kruize H., Brunekreef B., Hofschreuder P., de Meer G. and van Oudvorst A.B. (1995), Associations of PM10 and airborne iron with respiratory health of adults near a steel factory, $A m \mathrm{~J}$ Respir Crit Care Med, 152, 1932-1939.

EEA (2001), Air Pollution by Ozone in Europe in Summer 2001. European Environment Agency, Copenhagen. Office for Official Publications of the European Communities, Luxembourg. pp. 24.

EEA (2001a), Air Pollution by Ozone in Europe in 1999 and the Summer of 2000. European Environment Agency, Copenhagen. Office for Official Publications of the European Communities, Luxembourg. pp. 55

EEA (2002), Air Pollution by Ozone in Europe in Summer 2002. European Environment Agency, Copenhagen. Office for Official Publications of the European Communities, Luxembourg. pp. 23.

EEA (2003), Air Pollution in Europe 1990 - 2000. Topic Report 4/2003, European Environment Agency. Office for the Official Publications of the European Economic Communities, Luxembourg. Pp. 88.

Fenech G. (1998), The Canadian Acid Rain Strategy, Environmental Science \& Policy, 1, 261 - 267.

Fevnades S.A.P., Berneoux M., Cerri C.C., Feigl B.J. and Piccolo M.C. (2002), Seasonal Variation of Soil Chemical Properties and $\mathrm{CO}_{2}$ and $\mathrm{CH}_{4}$ Fluxes in Unfertilized and P-Fertilized Pastures in an Utisol of the Brazilian Amazon, Geoderma, 107(3-4), 227 - 241.

Folberth G., Ptister G., Baumgartner D., Putz E., Weissflog L. and Elansky N.P (2003), The Annual Course of TCA Formation in the Lower Troposphere: A Modeling Study, Environmental Pollution, 124(3), 389 405.

Fuhrer J. and Booker F. (2003), Ecological Issues Related to Ozone: Agricultural Issues, Environment International, 29(2-3), 141-154.

Funasaka K., Miyazaki T., Kawaraya T., Tsuruho K., Mizuno T., Nakajima H., Yamamoto T., Hara' H. (1999), A Case Study for Wintertime Observation of Atmospheric Particulates by an Eye-Safe Laser Radar, Environmental Pollution, 106(1), 47-53.

Gauvin J., Reungoat P., Cassadai S., Dechenaux J., Momas I., Just J. and Zimirou D. (2002), Contribution of Indoor and Outdoor Environments to $\mathrm{PM}_{2.5}$ Personal Exposure of Children VESTA Study, the Science of the Total Environment, 29, 175-181.

Glazunor V.I., Fatkhutdinov Z.A. and Magid A.B. (2001), Conversion of Acid Products of Industrial Emissions, Chemistry and Technology of Fuels and Oils, 37(5), 377 - 382.

Gundel L.A., Benner W.H. and Hansen A.D.A. (1994), Chemical Composition of Fog Water and Interstitial Aerosol in Berkeley, California, Atmospheric Environment, 28(16), 2715 - 2725.

Havens K.E., Yan N.D. and Keller W. (1993), Lake Acidification: Effects on Crustacean Zooplankton Populations, Environmental Science and Technology, 27(8), 1621 - 1624.

Heard A.C., Pilling M.J. and Tomlin A.S. (1998), Mechanism Reduction Techniques Applied to Tropospheric Chemistry, Atmospheric Environment, 32(6), 1059 - 1073.

Heinsohn R.J. and Kabel R.L (1999), Source and Control of Air Pollution. Prentice Hall Inc, Upper Saddle River NJ 07458. USA.

Hrdličková Z., Michálek J., Kolář M., and Veselý V. (2008), Identification of Factors Affecting Air Pollution by Dust Aerosol $\mathrm{PM}_{10}$ in Brno City, Czech Republic, Atmospheric Environment, 42(37), 8661-8673.

Huixiang W., Kiang C.S., Xiaoyan T., Xiuj Z., Chameides W.L., (2005), Surface Ozone: A Likely Threat to Crops in Yangtze delta of China, Atmospheric Environment, 39(21), 3843-3850

IPCC (1994), 'IPCC Guidelines for National Greenhouse Gas Inventories'. Intergovernmental Panel on Climate Change. Switzerland. Vol. $1-3$.

IPCC (1996), 'Revised IPCC Guidelines for National Greenhouse Gas Inventories'. Intergovernmental Panel on Climate Change. Switzerland. Vol. $1-3$.

Irwin J.G., Campbell G. and Vincent K. (2002), Trends in Sulphate and Nitrate Wet Deposition over the United Kingdom:1986 - 1999, Atmospheric Environment, 36(17), 2867 - 2879.

Jacob D.J. (2000), Heterogeneous Chemistry and Tropospheric Ozone, Atmospheric Environment, 34(12 14), $2131-2159$.

Jenkins M.E and Clemitshaw K.C (2000), Ozone and other Secondary Photochemical Pollutants: Chemical Processes Governing their Formation in the Planetary Boundary Layer, Atmospheric Environment, 34(16), 2499-2527

Johnson N.M. and Fegley Jr.B. (2002), Experimental Studies of Atmospheric-surface Interactions on Venus, Advances in Space Research, 29(2), 233 - 241. 
Kerminen V.M. and Wexker A.S. (1995), Growth Laws for Atmospheric Aerosol Particles: An Examination of the Bimodality of the Accummulation Mode, Atmospheric Environment, 29(22), 3263 - 3275.

Kjoller C., Postma D. and Larsen F. (2004), Groundwater Acidification and the Mobilization of Trace Metals in a Sandy Aquifer, Environ. Sci. Technol., 38(10), 2829 - 2835.

Knipping E.M. and Dabdub D. (2002), Modeling Surface-Mediated Renoxification of the Atmosphere via Reaction of Gaseous Nitric Oxide with Deposited Nitric Acid, Atmospheric Environment, 36(36 - 37), 5741-5748.

Kulshrestha U.C., Sarkar A.K., Srivastava S.S., and Parashar D.C. (1996), Investigation into Atmospheric Deposition through Deposition Studies at New Delhi (India), Atmospheric Environment, 30(24), 4149 4154.

Kumar P. and Mohan D. (2005), Photochemical Smog: Mechanism, III-Effects, and Control, TERI Information Digest on Energy and Environment, 1(3), 445.456

Lazaridis M. and Skouloudis A. (1999), Computer Simulation of the Transport, Formation and Dynamics of Atmospheric Sulphate Particles, Water, Air, and Soil Pollution, 112, 171 - 185.

Li S.C. and Williams F.A (1999), 'NO ${ }_{x}$ Formation in Two-Stage Methane-Air Flames', Combustion and Flame $118,399-414$.

Lia R.F., Chan C.W., Hromek J., Huang G.H. and He L (2008), Fuzzy Logic Control for Petroleum Separation Process, Engineering Applications of Artificial Intelligence, 21(6), 835 - 845.

Lieffering M.L., Kim H.M., Kobayashi K. and Okada M (2004), The Impacts of Elevated $\mathrm{CO}_{2}$ on the Elemental Concentration of Field-Grown Rice Grains, Field Crops Research, 88(2-3), 279 - 286.

Lightowlers P.J. and Cape J.N (1998), Sources and Fate of Atmospheric HCl in the UK and Western Europe, Atmospheric Environment, 22(1), 7 - 15.

Madhavi L.K and Badarinath K.V. (2004), Characterization of Aerosols and its Radiative Impacts over Urban and Rural Environments - A Case Study from Hyderabad and Srisailam, Environ Pollut., 132(3), 463-8.

Matsumoto K. and Tanaka H. (1996), Formation and Dissociation of Atmospheric Particulate Nitrate and Chloride: An Approach Based on Phase Equilibrium. Atmospheric Environment, 30(4), 639 - 648.

Menz F.C. and Seip H.M. (2004), Acid Rain in Europe and the United States: An Update, Environmental Science \& Policy, 7(4), $253-265$.

Michalski G., Böhlke J.K., Thiemens' M. (2004), Long Term Atmospheric Deposition as the Source of Nitrate and other Salts in the Atacama Desert, Chile: New Evidence from Mass-Independent Oxygen Isotopic Compositions, Geochimica et Cosmochimica Acta, 68(2), 4023-4038.

Mitra A.P. and Sharma C. (2002), Indian Aerosols: Present Status, Chemosphere, 49, 1175 - 1190.

Momen B., Anderson P.D., and Helms J.A. (1999). Temperature Dependency of Acid-Rain Effect on Photosynthesis of Pinus Ponderosa, Forest Ecology and Management, 113, 223 - 230.

Nazaroff W.W. and Weschler C.J. (2004), Cleaning Products and Air Fresheners: Exposure to Primary and Secondary Air Pollutants, Atmospheric Environment, 38(18), 2841-2865

NEGTAP (2001), Transboundary Air Pollution: Acidification, Eutrophication and Ground-Level Ozone in the UK. Prepared by the National Expert Group on Transboundary Air Pollution (NEGTAP) for UK Department for Environment, Food and Rural Affairs, Scottish Executive, The National Assembly for Wales/Cynulliad Cenedlaethol Cymru, Department of the Environment for Northern Ireland. DEFRA Contract EPG 1/3/153

Nelson M., Dempster W.F., Alling A., Allen J.P., Rasmussen R., Silverstone S. and Thillo M.V. (2003), Initial Experimental Results from the Laboratory Biosphere Closed Ecological System Facility, Advances in Space Research, 31(7): 1721 - 1730.

Okuda T., Iwase T., Ueda H., Suda Y., Tanaka S., Dokiye Y., Fushimi K. and Ho M. (2005), Long-term Trend of Chemical Constituents in Precipitation in Tokyo Metropolitan Area, Japan, from 1990 to 2002, Science of the Total Environment, 339(1 - 3), 127 - 141.

Park S.S., Ondov J.M., Harrison D. and Nair N.P. (2005), Seasonal and Shorter-Term Variations in Particulate Atmospheric Nitrate in Baltimore, Atmospheric Environment, 39, 2011-2020

Pawlowski L (1997), Acidification: Its Impact on the Environment and Mitigation Strategies, Ecological Engineering, 8(4): $271-288$.

Peart M.R. (2000), Acid Rain, Storm Period Chemistry and their Potential Impact on Stream Communities in Fong Kong, Chemosphere, 41(1-2), $25-31$.

Penner J.E. and Novakov T. (1996), Carbonaceous Particles in the Atmosphere: A Historical perspective to the Fifth International Conference on Carbonaceous Particles in the Atmosphere, Journal of Geophysical Research, 101, 19373 - 19378. 
Penkett S.A., Jones B.M.R., Brice K.A. and Eggleton A.E.J (2007), The Importance of Atmospheric Ozone and Hydrogen Peroxide in Oxidising Sulphur Dioxide in Cloud and Rainwater, Atmospheric Environment, 41(S1), 154-168

Pirjola L., Kulmala M., Wilck M., Bischoff A., Stratmann F. and Otto E. (1999), Formation of Sulphuric Acid Aerosols and Cloud Condensation Nuclei: An Expression for Significant Nucleation and Model Comparison, Journal of Aerosol Science, 30(8), 1079 - 1094.

Plummer D.A., McConnell J.C., Shepson P.B., Hastie D.R. and Niki H. (1996), Modeling of Ozone Formation at a Rural Site in Southern Ontario, Atmospheric Environment, 30(12), 2195 - 2217.

Pope C.A., Thun M.J., Namboodri M.M., Dockery D.W., Evans J.S., Speizer F.E. and Heath C.W. (1995), Particulate air pollution as a predictor of mortality in a prospective study of US adults, Amer. J. of Resp. Critical Care Med.,151, 669-674.

Ramanathan V., Crutzen P.J., Kiehl J.T. and Rosenfeld D. (2001), Aerosols, Climate, and the Hydrological Cycle, Science, 294(5549), 2119-24.

Raputa V.F., Smolyakov B.S. and Koutzenogii K.P (2008), Estimation of nitrate and sulfate content in snow in the vicinity of an oil-gas flare, Journal of Aerosol Science, 30, S655 - S656.

Renard J.J., Calidonna, S.E. and Henley M.V. (2004). Fate of Ammonia in the Atmosphere-A Review for Applicability to Hazardous Releases, Journal of Hazardous Materials, 108(1 - 2), 29-60.

Roemer W., Hoek G., Brunekreef B. (1993), Effect of Ambient Winter Air Pollution on Respiratory Health of Children with Chronic Respiratory Symptoms, Am Rev Respir Dis, 147, 118-124.

Russel A.G., McRae G.J., and Cass G.R. (1983), Mathematical Modeling of the Formation and Transport of Ammonium Nitrate Aerosol, Atmospheric Environment, 17(5), 949 - 964.

Ruth-Balaganskaya E. and Kudrijalt O (2002), Sulphur Migration in the Soil-Plant System Contaminated by Deposit from Nickel Industry: A Field Manipulation, Environmental Pollution, 117(2), 287 - 293.

Selma I., Macnhaut W., Pappi E.Z., and Zaray G. (2001), Comprehensive Characterization of Atmospheric Aerosol in Budapest, Hungary: Physicochemical Properties of Inorganic Species, Atmospheric Environment, 35, 4367 - 4378.

Sarwar G., Corsi R., Allen D. and Weschler C. (2003), The Significance of Secondary Organic Aerosol Formation and Growth in Buildings: Experimental and Computational Evidence, Atmospheric Environment, 37(9 - 10), 1365-1381

Satsangi G.S., Lakhani A., Khare P., Singh S.P., Kumari K.M. and Srivastava S.S. (2002), Measurements of Major Ion Concentration in Settled Coarse Particles and Aerosols at a Semiarid Rural Site in India, Environment International, 28(1-2): $1-7$.

Savabi M.R. and Stockle C.O (2001), Modeling the Possible Impact of Increases $\mathrm{CO}_{2}$ and Temperature on Soil Water Balance, Crop Yield and Soil Erosion, Environmental Modeling and Software,16(7), 631 640.

Song C.H, Chen G. and Davis D.D. (2003), Chemical Evolution and Dispersion of Ship Plumes in the Remote Marine Boundary Layer: Investigation of Sulphur Chemistry, Atmospheric Environment, 37(2), $2663-2679$.

Sonibare J.A. and Akeredolu F.A (2004), "A Theoretical Prediction of Non-methane Gaseous Emissions from Natural Gas Combustion”, Energy Policy, Netherlands, 32(14), 1653 - 1665.

Sonibare J.A. and Akeredolu F.A. (2005), Environmental Degradation Potential of Natural Gas Flares in Upstream Petroleum Operations, NAFTA Croatia, 56(3), 125 - 135

Stein A.F. and Lamb D. (2003), Empirical Evidence for the Low- and High-NOx Photochemical Regimes of Sulfate and Nitrate Formation, Atmospheric Environment, 37, 3615-3625

Strosher M.T (2000), Characterization of Emissions from Diffusion Flare Systems, Journal of Air and Waste Management Association, 50(10), 1723-1733.

Sun Y., Zhuang G., Wang Y., Han L., Guo J., Dan M., Zhang W., Wang Z. and Hao Z. (2004), The Air-Borne Particulate Pollution in Beijing-Concentration, Composition, Distribution and Sources, Atmospheric Environment, 38(35), 5991-6004.

Tecer L. (1999), Laboratory Experiments on the Investigation of the Effects of Sulphuric Acid on the Deterioration of Carbonate Stones and Surface Corrosion, Water, Air, and Soil Pollution, 114, 1-12.

Wang X. and Mauzerall D.L. (2004), Characterizing Distributions of Surface Ozone and its Impact on Grain Production in China, Japan and South Korea: 1990 and 2020, Atmospheric Environment 38 (26), 4383-4402

Watson A. and Nedwell D.B. (1998), Methane Production and Emission from Peat: the Influence of Anions (Sulphate and Nitrate) from Acid Rain. Atmospheric Environment, 32(19), 3289 - 3245.

Westnbearger D.A. and Frisvold G.B., (1994), Agricultural Exposure to Ozone and Acid Precipitation, Atmospheric Environment, 28(18), 2895 - 2907. 
WHO (2000), Air Quality Guidelines for Europe. World Health Organization Regional Office for Europe, Copenhagen, pp. $181-185$.

WHO (2002), The Health Effects of Indoor Air Pollution Exposure in Developing Countries. A Publication of the World Health Organization, Geneva, Switzerland. WHO/SDE/OEH/02.05.

Winiwarter W. and Puxbaum (2003), Investigations on the Formation of Secondary Organic Aerosol in the Vienna Vicinity. Proceedings of "Technology for Peace - Science for Mandkind" Topic: Particulate Matter and Health, $5^{\text {th }}$ International Technion Symposium of the Austrian Technion Society February 24 - 26, 2003, Vienna, Austria. pp. 8.

Xie S., Qi, L. and Zhou D. (2004), Investigation of the Effects of Acid Rain on the Deterioration of Cement Concrete using Accelerated Tests Established in Laboratory, Atmospheric Environment, 38, 44574466

Yen T.F. (1999). Environmental Chemistry: Essentials of Chemistry for Engineering Practice. Prentice Hall PTR, Upper Saddle River, New Jersey.

Yu S., Gao C., Cheng Z., Cheng X., Cheng S., Xiao J. and Ye W. (1998), An Analysis of Chemical Composition of Different Rain Types in 'Minnan Golden Triangle' Region in the Southeastern Coast of China, Atmospheric Research, 47-48, 245-269. 